\title{
Relationship between soft bottom macrofauna and polycyclic aromatic hydrocarbons (PAH) from smelter discharge in Norwegian fjords and coastal waters
}

\author{
Eivind Oug ${ }^{1, *}$, Kristoffer Næs $^{1}$, Brage Rygg ${ }^{2}$ \\ ${ }^{1}$ Norwegian Institute for Water Research, Southern Branch, Televeien 1, N-4890 Grimstad, Norway \\ ${ }^{2}$ Norwegian Institute for Water Research, PO Box 173 Kjelsås, N-0411 Oslo, Norway
}

\begin{abstract}
Data from monitoring surveys were used to test the responses of soft bottom fauna in Norwegian fjords and coastal waters affected by effluents from aluminium and manganese alloy smelters to effluent discharges. Generally, polycyclic aromatic hydrocarbons (PAHs) have been considered the main threat to the biota in the receiving waters. Data from a total of 57 quantitative stations, of which 30 were simultaneously sampled for sedimentary PAHs, were analysed. Canonical Correspondence Analysis (CCA) was used to evaluate species patterns in relation to sediment PAH concentrations and natural environmental variables such as depth, sediment characteristics and riverine input. The PAHs varied from very high concentrations $\left(760 \mu \mathrm{g} \mathrm{g}^{-1}\right.$ total PAH) at the most impacted sites to background levels in reference areas. Despite previous reports of little to no effects of the effluent discharges, the analyses identified significant species changes along PAH gradients, which could be associated with feeding modes. In particular, a number of carnivorous polychaetes had their distribution optima in the most affected areas. Based on species statistics calculated by CCA, response functions were fitted for the species on PAH and used to establish a generalised expression of trophic community structure in relation to PAH concentrations. At low PAH levels, the carnivores represented 15 to $20 \%$ of the specimens in the communities, but the proportion began to increase from about $10 \mu \mathrm{g} \mathrm{g}^{-1}$ and exceeded $50 \%$ at $100 \mu \mathrm{g} \mathrm{g}^{-1}$ total PAH. The faunal changes were most evident in shallow waters, possibly reflecting the effects of dissolved PAHs to which the species may react more directly than they do to sedimentary particle-associated PAHs.
\end{abstract}

KEY WORDS: Soft bottom fauna - Canonical Correspondence Analysis - PAH - Environmental effects Species response functions. Trophic structure

\section{INTRODUCTION}

The production of primary aluminium and manganese alloys is an important industrial activity in Norway, and Norwegian production accounts for a significant share of overall international capacity. A number of smelters are located along the west coast, mainly in narrow fjords or semi-enclosed coastal waters. Since the 1970s, environmental studies have been conducted in waters which receive waste discharge from the smelters. Waste effluents originating mainly from sea

•E-mail: eivind.oug@niva.no water scrubbing of furnace off-gases contain polycyclic aromatic hydrocarbons (PAHs), fluoride, soot particles from combustion processes and, in some cases, metals. PAHs have received the most attention as they have generally been considered the main threat to the receiving waters (Knutzen 1995). In monitoring studies, very high PAH concentrations have been documented in sediments and indicator organisms near effluent discharge areas (Næs et al. 1995). The concentrations decrease rapidly with distance from source, although elevated levels have been registered in the fjords several tens of kilometres away. However, the ecological effects appear to be small, except within restricted zones in the immediate vicin- 
ity of the effluent outfalls. Generally, it has been difficult to assess the role played by PAH in terms of the functioning of organisms in the receiving waters (Knutzen 1995).

In 2 of the fjords (Ardal and Sunndal), sediment PAH concentrations in excess of $700 \mu \mathrm{g} \mathrm{g}^{-1}$ dry weight, that is, more than 1000 times background levels, have been observed (Næes et al, 1995). In Ardal, there was no macrofauna in the most impacted area, but a speciesrich fauna was present in sediments containing 100 to $400 \mathrm{Hg} \mathrm{g}^{-1} \mathrm{PAH}$ at rather short distances (<600 m) from the abiotic zones (Knutzen 1995). In most fjords, no correlation has been found between faunal diversity and PAH levels. Knutzen (1995) actually suggested that the physical damage done to the habitat, rather than the PAH level, was the determining factor for benthic fauna in the most impacted areas.

The apparently limited ecological effects contrast with the toxicity of $\mathrm{PAH}$ reported from laboratory experiments and field studies conducted elsewhere (see e.g. compilations by Long 1992, Long et al. 1995). Knutzen (1995) suggested that the discrepancy might be related to the particle affinities of the PAHs. The majority of smelter effluent PAHs is associated with soot particles, which are presumably less available to organisms than PAHs in a dissolved state. Similar conclusions were reached by Paine et al. (1996), as they were unable to document toxicity from heavily PAHcontaminated sediments near a Canadian aluminium smelter. On the other hand, it is also possible that certain specific biological responses have been overlooked. The ecological effects in the Norwegian fjords were mainly assessed on the basis of faunal diversity at selected localities. Various recent studies (e.g. Olsgard \& Gray 1995) have shown that measures of diversity are not sufficiently sensitive to describe the full range of the effects of contaminants on soft bottom fauna.

The present study represents an integrated evaluation of soft bottom community data from various Norwegian fjords and surveys with particular emphasis on species patterns as related to PAHs and natural environmental factors. The data have been compiled from monitoring programmes conducted in the fjords since the mid-1970s. Different species' feeding modes were incorporated into the analyses to assess the relationships in view of biological features of the organisms. The analyses were performed using Canonical Correspondence Analysis (CCA), a multivariate direct gradient technique which relates species patterns to environmental variables (ter Braak 1986, Jongman et al. 1987, ter Braak \& Verdonschot 1995). PAH was treated as an environmental variable on a par with depth, sediment characteristics and riverine input. The main aims of the study were: (1) to describe the species assemblages along gradients based on PAHs and natural environmental factors, (2) to examine species distribution related to PAH gradients, and (3) to evaluate trophic community structure along PAH gradients. Data from fjords and coastal waters which do not receive industrial effluents were included in the analyses as a reference to provide environmental gradients in unimpacted systems.

\section{MATERIAL AND METHODS}

Fjords and sampling sites. Data were collected (Fig. 1) from 4 fjords which receive effluents from Al and Mn-alloy smelters ( $\AA$ rdal, Feda, Sauda, Sunndal). A total of 30 stations were sampled simultaneously for macrofauna and sedimentary $\mathrm{PAH}$, covering water depths from 28 to $375 \mathrm{~m}$ and spanning distances from immediate proximity to more than $10 \mathrm{~km}$ away from the effluent outfali points (Table 1). At the most contaminated sites, the PAH levels exceeded $100 \mu \mathrm{g} \mathrm{g}^{-1}$, far above the defined limit for very strong contamination (sum PAH $>20 \mu \mathrm{g} \mathrm{g}^{-1}$ ) set by Norwegian sediment quality criteria (Molvær et al. 1997). Values decreased with distance from the outfall points and approached background levels in some of the fjords. Details of the occurrence and distribution patterns of PAHs in the fjords are given by Næs et al. (1995) and Næs \& Oug $(1997,1998)$. The smelters are located near the heads

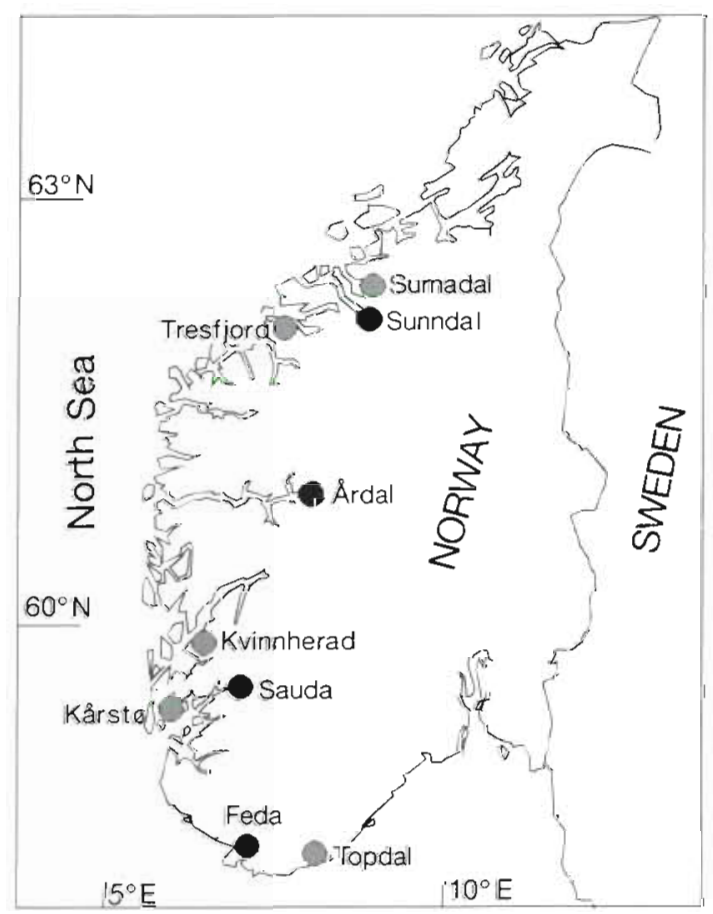

Fig. 1. Sampling sites in smelter-affected fjords (-) and reference areas $(0)$ 
Table 1. Summary data for macrofaunal stations in Norwegian fjords affected by smelter effluents and in reference fjords not influenced by industrial effluents. Type of smelter (aluminium, manganese alloy) is indicated. Distances from smelter effluent points, distances from major river outlets and PAH levels at the stations are shown. PAH ${ }_{13}$ : sum of PAHs from phenanthrene through benzolghiperylene (see text). ${ }^{\circ}$ given background value

\begin{tabular}{|c|c|c|c|c|c|c|}
\hline Fjord area & $\begin{array}{l}\text { Sampling } \\
\text { year }\end{array}$ & $\begin{array}{c}\text { No. of } \\
\text { stations }\end{array}$ & $\begin{array}{l}\text { Depth } \\
(\mathrm{m})\end{array}$ & $\begin{array}{l}\text { Distance from smelter } \\
\qquad(\mathrm{k} \cdot \mathrm{m})\end{array}$ & $\begin{array}{l}\text { Distance from river } \\
\qquad(\mathrm{km})\end{array}$ & $\begin{array}{r}\mathrm{PAH}_{13} \\
\left(\mathrm{\mu g} \mathrm{g}^{-1}\right)\end{array}$ \\
\hline Ärdal $(A l)$ & $\begin{array}{l}1983 \\
1989\end{array}$ & $\begin{array}{l}3 \\
4\end{array}$ & $\begin{array}{r}90-152 \\
110-165\end{array}$ & $\begin{array}{l}0.8-3.5 \\
1.0-3.5\end{array}$ & $\begin{array}{l}0.4-3.4 \\
0.7-3.4\end{array}$ & $\begin{array}{r}261-760 \\
96-298\end{array}$ \\
\hline Feda (Mn alloy) & 1984 & 5 & $28-88$ & $0.3-2.8$ & $0.4-2.8$ & $7-144$ \\
\hline Sauda (Mn alloy) & $\begin{array}{l}1976 \\
1981\end{array}$ & $\begin{array}{l}1 \\
5\end{array}$ & $\begin{array}{c}180 \\
40-375\end{array}$ & $\begin{array}{c}2.2 \\
0.4-9.5\end{array}$ & $\begin{array}{c}2.2 \\
0.5->5\end{array}$ & $\begin{array}{l}1.9 \\
1.9-143\end{array}$ \\
\hline Sunndal (Al) & $\begin{array}{l}1986 \\
1995\end{array}$ & $\begin{array}{l}8 \\
4\end{array}$ & $\begin{array}{r}60-328 \\
111-113\end{array}$ & $\begin{array}{l}0.8->10 \\
1.1->10\end{array}$ & $\begin{array}{l}1.6->5 \\
1.7->5\end{array}$ & $\begin{array}{l}1.1-123 \\
0.5-17\end{array}$ \\
\hline Topdal & 1983 & 8 & $33-198$ & $3.0->10$ & $0.4->5$ & $0.5^{\circ}$ \\
\hline Kvinnherad & 1990 & 5 & $31-186$ & $>10$ & $0.5->5$ & $0.5^{\circ}$ \\
\hline Kårste & 1983 & 5 & $35-134$ & $>10$ & $0.5->5$ & $0.5^{\circ}$ \\
\hline Surnadal & 1991 & 5 & $36-210$ & $>10$ & $0.7->5$ & $0.5^{\circ}$ \\
\hline Tresfjord & 1990 & 4 & $45-93$ & $>10$ & $1.2->5$ & $0.5^{\circ}$ \\
\hline
\end{tabular}

of the fjords and are close to major river outlets. In the fjords, the brackish water typically flows towards the mouth as a surface plume. All sampling stations were located beneath the brackish layer at salinities of 30 to 35 psu.

Due to the smelter locations, natural environmental factors dependent on, for example, topography and input of terrigenous materials may confound species patterns related to PAH contamination. In order to describe natural environmental conditions and be able to distinguish effluent effects from natural gradients, data were gathered from 5 fjords and coastal areas (Topdal, Kvinnherad, Kårstø, Surnadal, Tresfjord) unaffected by smelter effluents (Fig. 1, Table 1). Altogether, data were entered for 27 stations, representing, insofar as possible, the same depths and sediment types as in the smelter-affected fjords. In particular, fjords were selected on the basis of the influence exerted on them by riverine input.

Sampling and analysis. The faunal samples were taken using $0.1 \mathrm{~m}^{2}$ Petersen, Day or van Veen grabs. At each station, 2 to 8 , usually 4 to 5 , replicate samples were taken, sieved on $1 \mathrm{~mm}$ mesh sieves and preserved in $4 \%$ buffered formaldehyde solution. Collected specimens were identified to the species level in the majority of animal groups examined. The species were classified into 4 broad categories according to their general feeding modes (carnivores, surface deposit feeders, subsurface deposit feeders, suspension feeders) based on information from Fauchald \& Jumars (1979), Josefson (1986) and Gaston (1987). Most carnivores are vagile forms which can actively move about, whereas the other groups comprise sessile forms having very low mobility.

Surface sediment samples $(0$ to $1 \mathrm{~cm}$ ) for PAH analysis were usually obtained with a $5 \mathrm{~cm}$ internal diameter gravity corer, but subsamples were occasionally taken from the grabs. PAHs were analysed using gas chromatography fitted with flame ionizer detector (FID) or mass selective detector (MSD) on samples Soxhlet extracted in cyclohexane. The internal standards were 3,6-dimethylphenanthrene and $\beta, \beta$ binaphthyl for analysis with FID and 7 deuterated PAHs for analysis with MSD. The analytical quality assurance/control involved testing against standard reference material, where available. Details of the sampling and analytical methods, along with an overview of the distribution of the PAHs in the receiving waters, are presented by Næs et al. (1995).

Seabed conditions were visually characterised for all stations. In some of the fjords, surface sediments ( 0 to $1 \mathrm{~cm}$ ) were analysed for particle sizes (fine fraction) and organic matter. The fine fraction (silt-clay) was determined by wet sieving. Carbon and nitrogen were determined according to the measurement routine for total organic carbon (TOC), using a CHN analyser after the removal of inorganic carbonates.

Environmental variables. Environmental variables for the numerical analyses were designated for topography (water depth, distance from source, distance from river inflow points) and seabed conditions, as well as PAH and sediment characteristics. The distances to effluent outfalls and freshwater inflow points were used to describe spatial faunal patterns in the fjords. 
The distance from river inflow points represents the possible influence of freshwater and terrestrial riverborne materials, and was applied in order to distinguish natural fjord gradients from smelter effluent gradients. Seabed conditions were defined as a 4-class categorical variable based on the visual characterisation of the sediments (effluent-impacted sediment, organically enriched sediment, sandmixed mud and mud). Effluent-impacted sediment was recognized by the occurrence of black carbon particles. Topographical variables and seabed conditions were determined for all stations.

The PAHs were described using the total concentration $\left(\mathrm{PAH}_{13}\right)$ of 13 routinely measured compounds (phenanthrene, anthracene, fluoranthene, pyrene, benzola]anthracene, chrysene, benzo[bjk]fluoranthenes, benzo[e]pyrene, benzo[a]pyrene, perylene, indenopyrene, dibenzanthracene, benzo(ghi]perylene). Stations in the reference fjords were given an estimated background value $\left(\mathrm{PAH}_{13}=0.5 \mu \mathrm{g} \mathrm{g}^{-1}\right)$, so that PAH values were entered for all stations.

Numerical analyses. CCA provides a simultaneous ordination of species, samples and environmental variables. This technique arranges species and samples along axes which are constrained to be linear combinations of the environmental variables. Accordingly, the faunal patterns displayed can be related to the variables (ter Braak 1986, Jongman et al. 1987, ter Braak \& Verdonschot 1995). The importance of the relationships is reflected by the amount of species variance (referred to as 'inertia') that can be extracted on the axes. This is measured by the eigenvalues of the axes, which can be compared with the total variance in the species data ('total inertia') for the purpose of quantifying how much of the variation for which the variables may account. The total inertia is calculated as the sum of all unconstrained eigenvalues in Correspondence Analysis (CA). Diagrams are presented as combined plots (biplots) of species and environmental variables. Species are marked by points, representing their most preferred position (distribution optimum) in relation to the variables. The variables are indicated by vectors (quantitative variables) pointing in the direction of maximum value of the variable. Long vectors indicate strong trends, and the angle between pairs of vectors approximates the correlation between the respective variables. Categorical variables are designated by points for the variable classes.

The analyses were carried out with the program CANOCO, version 3.10 (ter Braak 1988, 1990), while diagrams were constructed with the drawing program CanoDraw 3.0 (Smilauer 1992). Three analyses were carried out. In the first analysis, general faunal gradients and responses to PAH contamination in the fjords were illustrated using data from all stations. Data on depth, distance from smelter, distance from river inflow points and PAH were entered as quantitative variables, while the bottom sediments were represented by the categorical variable for seabed conditions. In the second analysis, faunal gradients were assessed from 2 fjords (Sunndal and Surnadal) where quantitative sediment variables had also been obtained. Prior to analysis, topographical variables and PAH concentrations were $\log$-transformed to make adjustment for skewed distributions. Species data for replicate samples were pooled for each station, recalculated as densities (ind. $\mathrm{m}^{-2}$ ), and square-root transformed to down-weight high densities. The procedure of 'forward selection' and Monte Carlo permutation tests were used to rank the variables in order of importance, and to identify a subset of significant variables maximally related to species distribution. In the plots, species' feeding modes were entered in order to illustrate functional relationships on PAH and environmental gradients.

The third analysis focused particularly on species distribution related to PAH. This analysis was carried out with $\mathrm{PAH}$ as the only environmental variable, implying that the first $\mathrm{CCA}$ axis turns into a linear gradient for PAH on which species are arranged in order. The variables of depth and distance from river outlet points were entered as covariables in order to eliminate variation related to these factors. For each species, statistics were calculated to determine the distribution centre on the gradient (optimum) and the spread along the gradient (tolerance). These statistics were utilised in a subsequent analytical step to fit response curves for the species on the PAH gradient. The curves were fitted according to the Gaussian function ( $=$ normal distribution), assuming unimodal species distributions

$$
Y_{I}=c_{1} \exp \left[-0.5\left(x-u_{j}\right)^{2} / t_{i}{ }^{2}\right]
$$

where $Y_{i}$ is the estimated density of species $i$ for the value $(x)$ on the gradient (PAH concentrations), $c_{1}$ the maximum density, $u_{l}$ the optimum and $t_{l}$ the tolerance ('standard deviation'). The maximum density $c_{l}$ was estimated by taking the total species weight (the sum of observed densities) divided by the parameter $N_{2}$, measuring the number of samples in which the species is well represented ('the effective number of occurrences': ter Braak 1990, ter Braak \& Verdonschot 1995). Values for $u, t$, total weight and $N_{2}$ are supplied in the output from the CANOCO processing. The analysis was performed on untransformed species values due to the fitting of the species curves.

The fitted species curves were used to develop a generalised expression of functional relationships along a PAH gradient. To manage this, all species were classified according to their feeding modes and their response functions were added up across species within the different feeding groups. The resultant dia- 
gram illustrates a model of the community's trophic composition in relation to $\mathrm{PAH}$.

\section{RESULTS}

\section{Fauna and sediments}

In most fjords, the number of species sampled per station varied from 30 to 70 (Table 2). In Ardal, however, few species were found at the stations on the periphery of the afaunal zone close to the outfall. Moreover, a reduced number of species was detected at the most contaminated stations in Feda and Sauda. For the most part, the Shannon-Wiener diversity index ranged from 2.5 to 5.0. Apart from at the most highly impacted stations, species numbers and diversity did not differ between the smelter-affected fjords and the fjords not receiving industrial effluents. Table 3 lists the species included in the analyses (a total of 97 species) and includes summary information about their occurrence in the fjords.

Some stations close to effluent outfalls had dark grey or black sediments with a high TOC value and $\mathrm{C} / \mathrm{N}$ ratio (Årdal, Sunndal) (Table 2). This is presumably due to effluent soot particles having become embedded in the sediments (Næs \& Oug 1997, 1998). Soot carbon is not distinguished from naturally occurring organic carbon by the ordinary analysis for TOC. In Sunndal, the $\mathrm{TOC}$ value and $\mathrm{C} / \mathrm{N}$ ratio correlate with PAH concentrations (Næs \& Oug 1998).

\section{Main faunal patterns in the fjords}

The basic CCA revealed significant faunal patterns related to depth, distance from freshwater inflow points, sediment types and smelter effluents (Table 4). In particular, the PAH level $\left(\mathrm{PAH}_{13}\right)$ figured among the variables explaining the relatively higher fractions of species variance. Using the forward selection procedure, the variables of depth, distance from river, $\mathrm{PAH}$ level and distance from smelter were selected and ranked as the most important variables. However, the fraction of explained species variance (23\%) was rather low. To some degree, this reflects the structure of the analysis, given that data sets from different fjords with different species assemblages were put together in combination. In a separate analysis (not shown here), inter-fjord differences were estimated to account for about $40 \%$ of the total species variance.

The variables of depth and distance from river correlated most strongly with the first and second CCA axes. The plot of these axes (Fig. 2A) displays the species according to gradients in depth and river inflow, which may be representative of natural faunal gradients in the fjords. Species positioned at the lower left, i.e. in the negative direction of the depth variable, had their distribution optima in relatively shallow waters (e.g. Amphiura filiformis and Edwardsiidae), while species at the upper right, i.e. in the positive direction, had their optima at the deepest stations (e.g. Thyasira gouldi and Kelliella miliaris). Species marked near the centre of the plot either were found in intermediate depths, or were present at

Table 2. Summary data for macrofauna and sediment variables in Norwegian fjords affected by smelter effluents and in reference fjords not influenced by industrial effluents. $H^{\prime}$ : Shannon-Wiener diversity index $(\log 2$ base). TOC: total organic carbon. na: not analysed

\begin{tabular}{|c|c|c|c|c|c|c|c|c|}
\hline Fjord area & Year & $\begin{array}{l}\text { No. of } \\
\text { stations }\end{array}$ & $\begin{array}{l}\text { No. of } \\
\text { species }\end{array}$ & Ind. $\mathrm{m}^{-2}$ & $H^{\prime}$ & $\begin{array}{c}\text { Silt+clay } \\
(\%)\end{array}$ & $\begin{array}{l}\text { TOC } \\
(\%)\end{array}$ & $\mathrm{C} / \mathrm{N}$ ratio \\
\hline Ardal & $\begin{array}{l}1983 \\
1989\end{array}$ & $\begin{array}{l}3 \\
4\end{array}$ & $\begin{array}{l}22-45 \\
45-56\end{array}$ & $\begin{array}{c}246-612 \\
1024-1479\end{array}$ & $\begin{array}{l}1.7-4.3 \\
3.1-3.9\end{array}$ & $\begin{array}{c}\text { na } \\
40-57\end{array}$ & $\begin{array}{l}5.4-15 \\
2.5-6.6\end{array}$ & $\begin{array}{l}49-80 \\
25-65\end{array}$ \\
\hline Feda & 1984 & 5 & $19-56$ & $683-1760$ & $2.2-5.0$ & na & $2.6-5.1^{\mathrm{a}}$ & na \\
\hline Sauda & $\begin{array}{l}1976 \\
1981\end{array}$ & $\begin{array}{l}1 \\
5\end{array}$ & $\begin{array}{c}16 \\
2-20\end{array}$ & $\begin{array}{c}1670 \\
25-360\end{array}$ & $\begin{array}{c}2.5 \\
1.6-4.0\end{array}$ & $\begin{array}{l}\text { na } \\
\text { na }\end{array}$ & $\begin{array}{l}1.3^{\mathrm{a}} \\
\text { na }\end{array}$ & $\begin{array}{l}\text { na } \\
\text { na }\end{array}$ \\
\hline Sunndal & $\begin{array}{l}1986 \\
1995\end{array}$ & $\begin{array}{l}8 \\
4\end{array}$ & $\begin{array}{l}30-48 \\
98-127\end{array}$ & $\begin{array}{l}1625-3835 \\
3500-5703\end{array}$ & $\begin{array}{l}2.5-3.9 \\
4.3-5.6\end{array}$ & $\begin{array}{l}30-90 \\
36-74\end{array}$ & $\begin{array}{l}0.4-3.9 \\
0.6-1.4\end{array}$ & $\begin{array}{r}11-25 \\
8-12\end{array}$ \\
\hline Topdal & 1983 & 8 & $40-60$ & $450-8748$ & $2.0-4.6$ & na & $0.9-4.4$ & $11-15$ \\
\hline Kvinnherad & 1990 & 5 & $40-81$ & $350-1292$ & $3.5-5.2$ & na & $0.3-2.0$ & $10-11$ \\
\hline Kårstø & 1983 & 5 & $23-90$ & $516-3674$ & $2.5-4.9$ & na & na & na \\
\hline Surnadal & 1991 & 5 & $38-70$ & $1090-5020$ & $3.2-4.6$ & $41-97$ & $0.7-1.8$ & $9-14$ \\
\hline Tresfjord & 1990 & 4 & $51-72$ & $1150-1770$ & $3.7-4.7$ & na & $3.6-5.2$ & $10-13$ \\
\hline
\end{tabular}


Table 3. List of species included in the ordination analyses. Trophic group (TR) and number of recordings (Rec) are also indicated (total number of stations $=57$ ). Trophic groups: $\mathrm{c}=$ carnivore (also including omnivore), sd $=$ surface deposit feeder, ssd $=$ subsurface deposit feeder, sus = suspension feeder. TR classification is in accordance with Fauchald \& Jumars (1979), Josefson (1986) and Gaston (1987). All species with a total number of specimens $>15$, equivalent to 0.5 per thousand of total abundances are included

\begin{tabular}{|c|c|c|c|c|c|}
\hline Species & $\mathrm{TR}$ & Rec & Species & TR & Rec \\
\hline ANTHOZOA & \multirow{3}{*}{$\mathrm{c}$} & \multirow{3}{*}{3} & Pista cristata & sd & 22 \\
\hline \multirow[t]{2}{*}{ Edwardsiidae ind. } & & & Streblosoma intestinalis & sd & 12 \\
\hline & & & Terebellides stroemi & $s d$ & 37 \\
\hline \multirow[t]{2}{*}{ NEMERTINEA ind. } & \multirow[t]{3}{*}{ c } & \multirow[t]{3}{*}{47} & Chone sp. & sus & 21 \\
\hline & & & Euchone sp. & sus & 10 \\
\hline POLYCHAETA & & & Jasmineira sp. & sus & 13 \\
\hline Paramphinome jeffreysii & c & 36 & & & \\
\hline Harmothoe sp. & c & 30 & OLIGOCHAETA ind. & ssd & 5 \\
\hline Pholoe minuta & c & 36 & & & \\
\hline Sthenelais sp. & c & 7 & OPISTOBRANCHIA & & \\
\hline Eteone sp. & c & 21 & Philine scabra & c & 17 \\
\hline Phyllodoce groenlandica & c & 14 & Philine sp. & c & 12 \\
\hline Nereimyra punctata & $c$ & 20 & & & \\
\hline Ophiodromus flexuosus & c & 31 & CAUDOFOVEATA ind. & c & 32 \\
\hline Exogone verugera & sd & 25 & & & \\
\hline Typosyllis cornuta & $c$ & 22 & BIVALVIA & & \\
\hline Ceratocephale loveni & sd & 23 & Nucula sulcata & ssd & 8 \\
\hline Nephtys incisa & $\mathrm{c}$ & 16 & Nuculoma tenuis & ssd & 18 \\
\hline Glycera alba & c & 26 & Yoldiella lucida & ssd & 14 \\
\hline Glycera capitata & c & 22 & Yoldiella tomlini & ssd & 9 \\
\hline Goniada maculata & $\mathrm{c}$ & 35 & Thyasira croulinensis & ssd & 11 \\
\hline Lumbrineris gracills & c & 10 & Thyasira equalis & ssd & 31 \\
\hline Lumbrineris scopa & $\mathrm{c}$ & 18 & Thyasira ferruginea & ssd & 17 \\
\hline Lumbrineris sp. & c & 35 & Thyasira gouldi & ssd & 4 \\
\hline Protodorvillea kefersteini & c & 5 & Thyasira obsoleta & ssd & 13 \\
\hline Phylo norvegica & ssd & 17 & Thyasira pygmaea & ssd & 9 \\
\hline Scoloplos armiger & ssd & 9 & Thyasira flexuosa/sarsi & ssd & 27 \\
\hline Apistobranchus tullbergi & sd & 11 & Thyasira sp. & ssd & 17 \\
\hline Aricidea sp. & sd & 16 & Mysella bidentata & sus & 8 \\
\hline Paraonis gracilis & sd & 18 & Parvicardium minimum & sus & 16 \\
\hline Paradoneis lyra & sd & 20 & Abra nitida & sd & 34 \\
\hline Laonice cirrata & $s d$ & 12 & Arctica islandica & sus & 5 \\
\hline Polydora sp. & sd & 7 & Kelliella milians & sus & 14 \\
\hline Prionospio cirrifera & sd & 38 & & & \\
\hline Prionospio malmgreni & sd & 21 & CRUSTACEA & & \\
\hline Prionospio sp. & $s d$ & 7 & Eudorella emarginata & sd & 25 \\
\hline Pseudopolydora antennata & sd & 24 & Eudorella truncatula & sd & 8 \\
\hline Spiophanes kroeyeri & sd & 34 & Leucon nasica & sd & 19 \\
\hline Caulleriella sp. & sd & 24 & Diastylopsis resima & $s d$ & 4 \\
\hline Chaetozone setosa & sd & 43 & Tanaidacea ind. & sd & 8 \\
\hline Tharyx sp. & sd & 30 & Eriopisa elongata & sus & 18 \\
\hline Diplocirrus glaucus & sd & 39 & Westwoodilla caecula & c & 21 \\
\hline Asclerocheilus intermedius & $s d$ & 3 & Harpinia sp. & C & 18 \\
\hline Polyphysia crassa & ssd & 17 & & & \\
\hline Scalibregma inflatum & ssd & 23 & SIPUNCULIDA & & \\
\hline Notomastus latericeus & ssd & 13 & Golfingia sp. & ssd & 11 \\
\hline Heteromastus filiformis & ssd & 47 & Onchnesoma steenstrupi & ssd & 7 \\
\hline Asychis biceps & ssd & 8 & Sipunculida ind. & ssd & 14 \\
\hline Euclymene sp. & ssd & 22 & & & \\
\hline Myriochele oculata & sd & 25 & ECHINODERMATA & & \\
\hline Owenia fusiformis & sd & 6 & Amphiura chiajei & sd & 20 \\
\hline Pectinana auricoma & ssd & 16 & Amphiura filiformis & sus & 12 \\
\hline Amythasides macroglossus & sd & 20 & Ophiura sp. & sd & 23 \\
\hline Eclysippe vanelli & $\mathrm{sd}$ & 15 & Echinocardium cordatum & ssd & 8 \\
\hline Melinna cristata & sd & 18 & Labidoplax buski & ssd & 21 \\
\hline Melythasides laubieri & sd & 4 & Leptosynaptasp. & ssd & 8 \\
\hline Sosane sulcata & sd & 7 & & & \\
\hline
\end{tabular}


shallow and deep stations alike. Species at the upper left (e.g. oligochaetes and Thyasira flexuosa/sarsi) were found near river inflow points, suggesting that they are stimulated by riverborne materials. The variables of $\mathrm{PAH}$ level and distance from smelter correlated with the third CCA axis (Fig. 2B). The species in the upper part of the diagram were found near effluent outfall points (e.g. Protodorvillea kefersteini and Nereimyra punctata) while the species in the lower part were found far from the outfalls (e.g. oligochaetes, Onchnesoma steenstrupi and Echinocardium cordatum). The different orientation of the vectors for distance from river and PAH level makes it possible to discriminate between natural faunal gradients and species patterns attributable to smelter effluents.

The species plots which indicate feeding groups are illustrated in Fig. 3. The feeding groups formed a mosaic pattern dependent on depth and river inflow, but carnivores tended to be most abundant in shallow waters, and there was a preponderance of deposit feeders in deeper waters distant from river inflow points (Fig. 3A). However, clearer patterns began to emerge in relation to $\mathrm{PAH}$ levels and distance from smelter effluents. In the plots for axes 1 and 3 (Fig. 3B),

Table 4. Canonical Correspondence Analysis (CCA) for soft bottom macrofauna at stations contaminated by PAHs and in reference areas in Norwegian fjords, showing cigenvalues, percentages of extracted variance and correlation to environmental variables for the first 4 axes. The 'forward selection' procedure was used to rank environmental variables by importance. Inertia: extracted variance attributable to each individual variable. Added inertia: added variance accounted for by variables selected one by one in sequence. The variables found significant $(p<0.05)$ in Monte Carlo permutation tests were selected. Asterisks denote classes of categorical seabed variables. The data comprise 57 stations and 97 species/ species groups

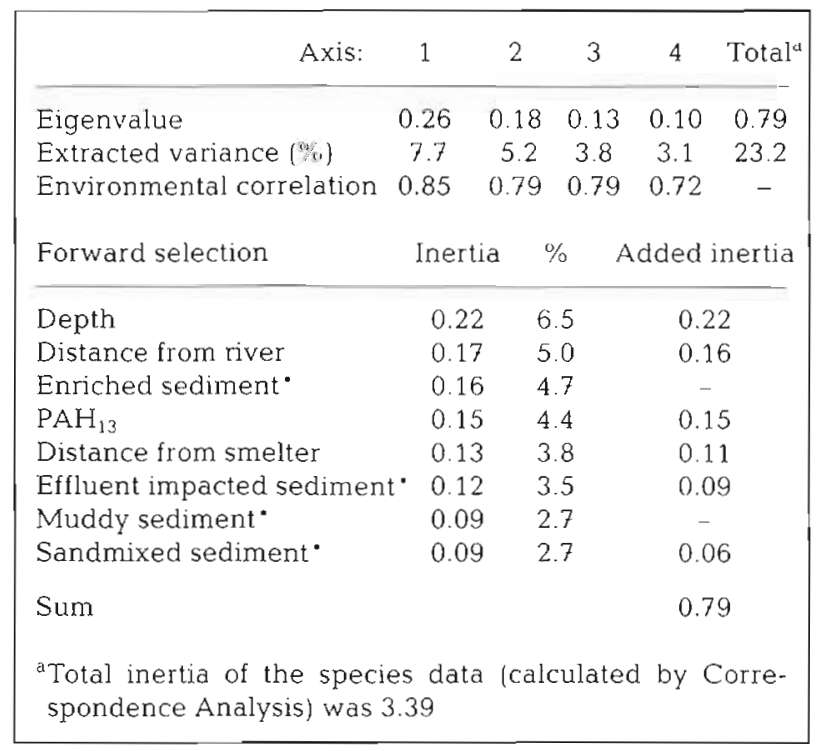

carnivores were in a majority in the upper left quadrant, representing shallow waters near the smelters. This contrasts with the lower left quadrant, representing shallow waters distant from the smelters, where
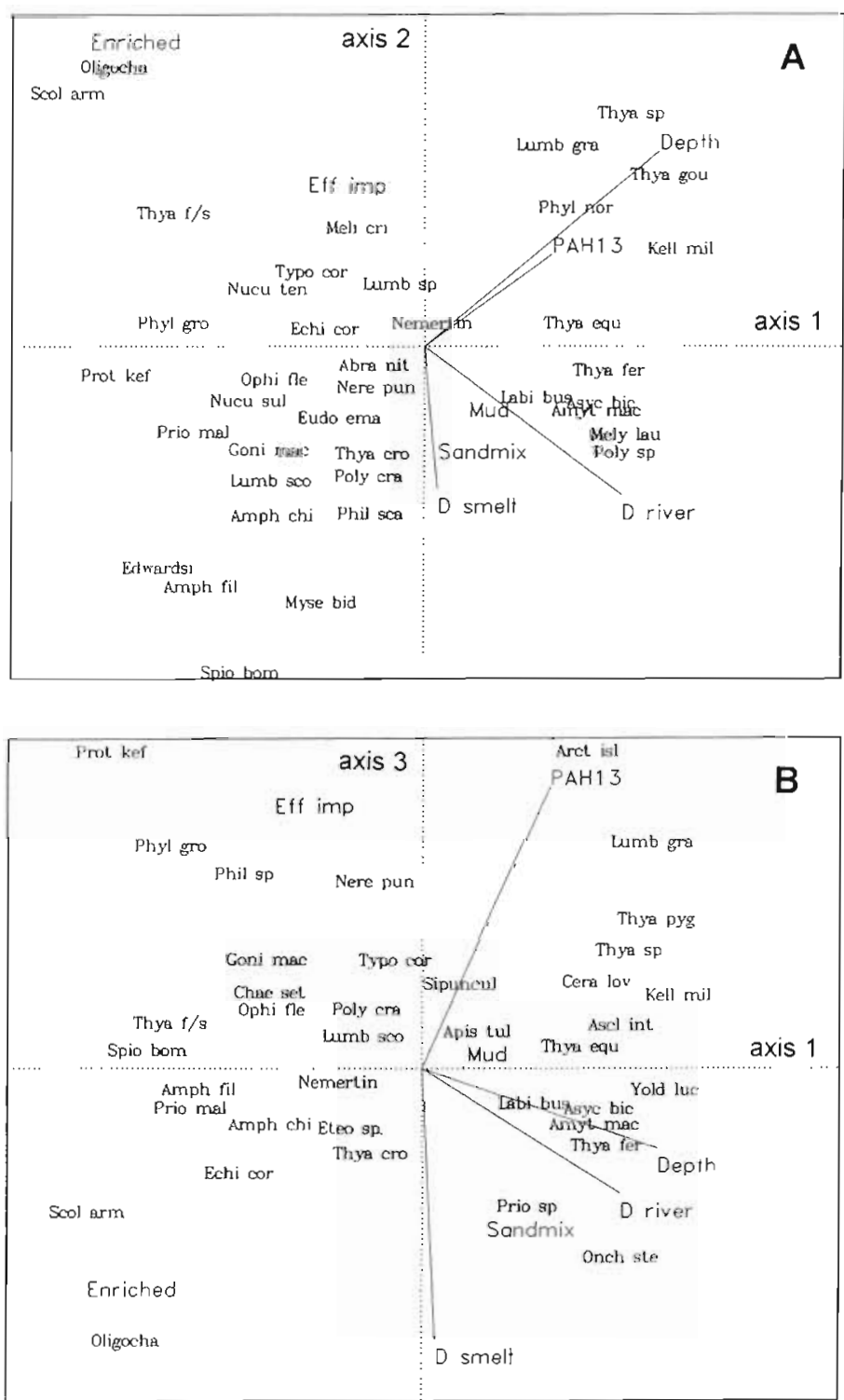

Fig. 2. Canonical Correspondence Analysis (CCA) of soft bottom macrofauna in Norwegian fjords affected by aluminium smelter effluents and in reference areas: biplot of species and environmental variables for (A) axes 1 and 2 and (B) axes 1 and 3. Quantitative variables are indicated by vectors pointing in the direction of maximum value of the variables; $D$ smelt = distance from smelter D river = distance from river inflow point. Classes of categorical seabed variable are indicated by centroids; Eff imp = effluent-impacted sediment; Enriched = organically enriched sediment. A selection of characteristic species is shown; other species have been omitted for clarity. Species names are given in full in Table 3. Plots account for 13 and $11 \%$ of the total species variation (total inertia) and 56 and $49 \%$ of the explainable variation, respectively. Data for the analysis are given in Table 4 
there was an aggregation of deposit and suspension feeders. It should be noted that most deposit and suspension feeders were located in a band parallel to the first axis, reflecting their occurrence in both shallow and deep water, and at varying distances from river inflow points. The result suggests that the smelter effluents favour carnivorous species, or conversely, are negative to deposit feeders. These effects tend to be most prominent in shallow waters and moderate depths.
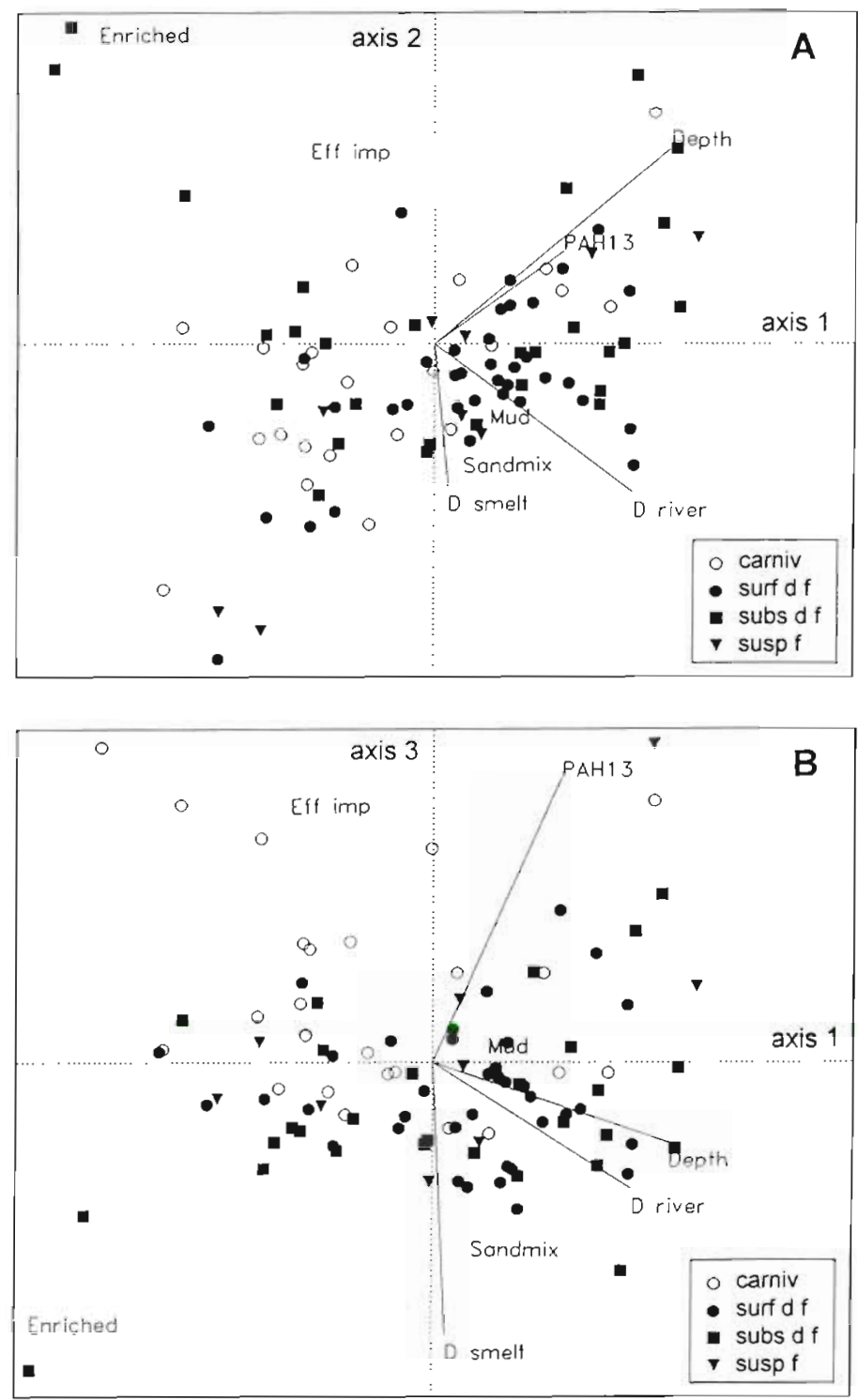

Fig. 3. CCA biplot of species and environmental variables from analyses of soft bottom macrofauna in Norwegian fjords with symbols representing feeding categories superimposed on species positions (carniv: carnivores; surf d f: surface deposit feeders; subs d f: subsurface deposit feeders; susp f: suspension feeders). (A) Axes 1 and $2 ;(B)$ axes 1 and 3. Names of most important species and other abbreviations as indicated in Fig. 2

\section{Sunndal and Surnadal fjords}

The CCA for the Sunndal and Surnadal fjords, where quantitative sediment variables were obtained, revealed largely the same faunal patterns as in the main analysis. TOC and the $\mathrm{C} / \mathrm{N}$ ratio were among the most important variables, but they were clearly related to the distance from the smelter and correlated with PAH levels (Fig. 4, Table 5). In the plot, most carnivores had their optima in the direction of increasing PAH levels, while most deposit feeders were located at a distance from river inflow points and smelter effluents with moderate and low TOC and $\mathrm{C} / \mathrm{N}$ values. In forward selection, the $\mathrm{C} / \mathrm{N}$ ratio was ranked at the top and selected together with depth, $\mathrm{PAH}_{13}$ and the categorical variable of effluent-impacted sediment. The distance variables, TOC and other sediment categories tended not to contribute any significant additional information, obviously because of intercorrelations. The silt-clay fraction showed little correlation with species distribution. The results for the $\mathrm{C} / \mathrm{N}$ ratio and TOC appear to reflect the effects of effluent soot parti-

Table 5. CCA for soft bottom macrofauna in the Sunndal and Surnadal fjords, showing eigenvalues, percentages of extracted variance and correlation to environmental variables for the first 4 axes. The 'forward selection' procedure was used to rank environmental variables by importance. Inertia: extracted variance attributable to each individual variable. Added inertia: added variance accounted for by variables selected one by one in sequence. The variables found significant $(\mathrm{p}<0.05)$ in Monte Carlo permutation tests were selected. Asterisks denote classes of categorical seabed variables. The data comprise 1.7 stations and 89 species/species groups

\begin{tabular}{|lccccc|}
\hline Axis: & 1 & 2 & 3 & 4 & Total $^{\prime}$ \\
\hline Eigenvalue & 0.28 & 0.20 & 0.17 & 0.08 & 0.73 \\
Extracted variance (\%) & 20.1 & 14.8 & 12.2 & 5.7 & 52.9 \\
Environmental correlation & 0.96 & 0.96 & 0.98 & 0.95 & -
\end{tabular}

\begin{tabular}{lccc} 
Forward selection & Inertia & $\%$ & Added inertia \\
\hline C/N ratio & 0.25 & 18.1 & 0.25 \\
Depth & 0.21 & 15.2 & 0.19 \\
Effluent impacted sediment & 0.21 & 15.2 & 0.18 \\
Distance from river & 0.18 & 13.0 & - \\
TOC & 0.17 & 12.3 & - \\
Distance from smelter $^{\text {PAH }}{ }_{13}$ & 0.16 & 11.6 & - \\
Sandmixed sediment $^{*}$ & 0.15 & 10.9 & 0.11 \\
Muddy sediment $^{*}$ & 0.14 & 10.1 & - \\
Silt-clay & 0.13 & 9.4 & - \\
Sum & 0.08 & 5.8 & - \\
& & & 0.73 \\
"Total inertia of the species data & (calculated by Corre- \\
spondence Analysis) was 1.38 & &
\end{tabular}




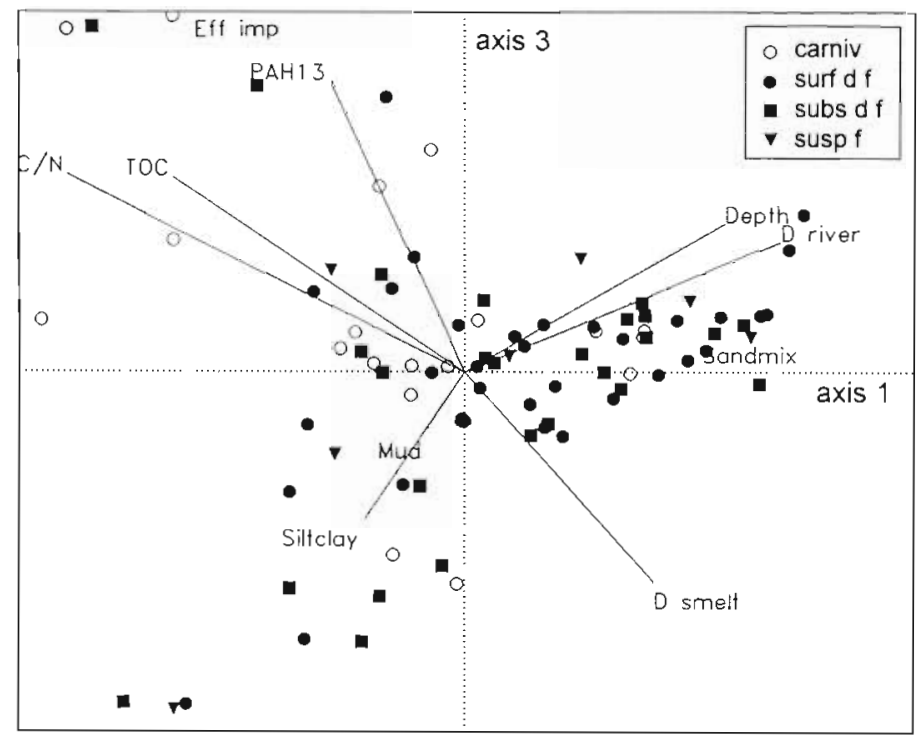

Fig. 4. CCA biplot of species and environmental variables (axes 1 and 3) of soft bottom macrofauna in Sunndal and Surnadal fjords with species shown by symbols representing feeding categories. The variables $\mathrm{C} / \mathrm{N}$, depth, effluent-impacted sediment and $\mathrm{PAH}_{13}$ were active in the analysis, while other variables entered on the diagram were passive variables. TOC: total organic carbon; other abbreviations as in Fig. 2. The plot accounts for $32 \%$ of the total speries variation (total inertia) and $62 \%$ of the explainable variation. Data for the analysis given in Table 5

cles in the sedimentary carbon pool (Næes \& Oug 1998). The results suggest that depth and effluents are the most salient factors for species distribution.

Table 6. Ranking of species with respect to trophic status and major systematic groups along a gradient determined by PAH concentrations. For each case, average ranks were calculated for species allocated in 2 groups; difference between groups were tested using Mann-Whitney U-test for 2 independent samples. (A) Carnivores compared with non-carnivores: all species ( 97 species), only polychaetes (57 species), and nonpolychaetes (40 species). (B) Major systematic groups; indicated group compared with rest of species. High average ranks indicate positive correlation with PAH. Probabilities $(\mathrm{p})$ refer to 2 -tailed tests. Significance values: $p<<0.05 ; \cdots p<$ 0.01; ns- notsignificant

\begin{tabular}{|lcrr|}
\hline Faunal category & No. of species & Average rank & $\mathrm{p}$ \\
\hline $\begin{array}{l}\text { (A) Carnivores vs non-carnivores } \\
\text { All species }\end{array}$ & & \\
Polychaetes & $17: 40$ & $38.7: 24.9$ & $<0.01^{\circ}$ \\
Non-polychaetes & $7: 33$ & $19.0: 20.8$ & $0.72 \mathrm{~ns}$ \\
(B) Systematic groups & & & \\
Polychaeta & $57: 40$ & $52.7: 43.7$ & $0.12 \mathrm{~ns}$ \\
Mollusca & $20: 77$ & $51.5: 48.4$ & $0.67 \mathrm{~ns}$ \\
Crustacea & $8: 89$ & $47.6: 49.1$ & $0.89 \mathrm{~ns}$ \\
Echinodermata & $6: 91$ & $25.1: 50.6$ & $0.03^{\circ}$ \\
\hline
\end{tabular}

\section{Faunal changes in relation to $\mathrm{PAH}$ contamination}

The primary yield of the CCA with $\mathrm{PAH}_{13}$ entered as the sole variable was an ordering of the species along a PAH concentration gradient. The species were ordered by their calculated optima with respect to PAH. The gradient (the first axis) explained a rather small fraction of the total species variance $(5 \%)$, but it was found statistically significant $(p<0.05)$ using Monte Carlo permutation tests. This rather small variance may, as in the basic CCA discussed above, reflect the combination of different data sets in the analysis. The covariables (depth, distance from river outlet points) accounted for $12 \%$ of the total variance. The ordered list of species exhibited a proportional dominance of carnivores in connection with high PAH values. This trophic pattern proved significant when tested for the distribution of carnivores versus non-carnivores along the gradient (Table 6). It was, however, among the polychaetes that a clear difference was apparent between carnivores and non-carnivores. Tests were also carried out for each of the major faunal groups to assess their overall distribution along the PAH gradient (Table 6). These indicated a significant correlation between echinoderms and low PAH values, suggesting that these species may generally avoid PAH-contaminated areas, whereas other groups were more evenly dispersed. With the notable exception of carnivores, rather few species had their optima at high PAH concentrations. The decrease was most pronounced among deposit feeders (Fig. 5)

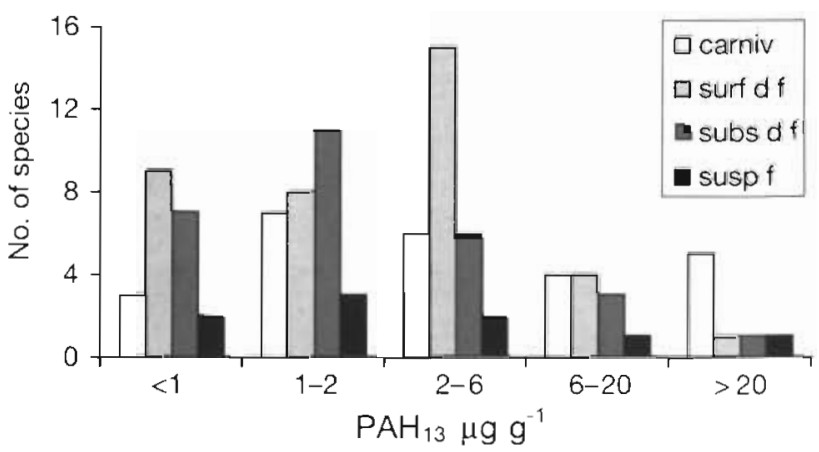

Fig. 5. Number of species in feeding categories (carnivi carnivores; surf d f: surface deposit feeders; subs d f: subsurface deposit feeders; susp f: suspension feeders) in relation to different PAH concentration levels. Species are represented by their optima (peak distribution centre) on the PAH gradient. Classification of species is shown in Table 3 


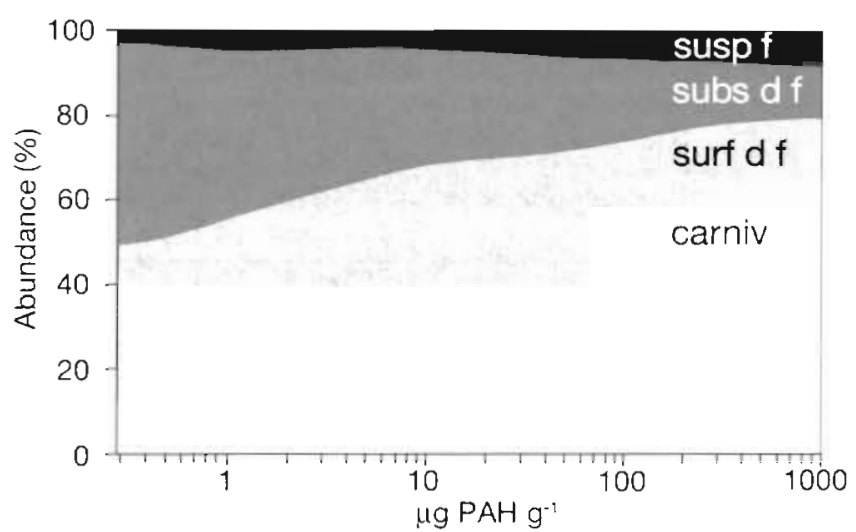

Fig. 6. Estimated trophic composition of species communities along the PAH concentration gradient. Classification of species into feeding categories (carniv: carnivores; surf $d \mathrm{f}$ : surface deposit feeders; subs d f: subsurface deposit feeders; susp f: suspension feeders) shown in Table 3

The generalised model of the community's trophic composition along the PAH gradient, generated from fitted response curves for the species, is shown in Fig. 6. There is a clear relative dominance of carnivores at high PAH levels. At low PAH levels, surface and subsurface deposit feeders dominate, while carnivores account for 15 to $20 \%$ of the specimens. The carnivores begin to increase at PAH levels of roughly $10 \mathrm{\mu g} \mathrm{g}^{-1}$ and exceed $50 \%$ at $100 \mathrm{\mu g} \mathrm{g}^{-1}$. The carnivore curve flattens out at levels in excess of $300 \mathrm{\mu g} \mathrm{g}^{-1}$, but the reliability of the estimates in this part of the diagram is likely to be poor since there are very few data available for these high PAH levels. The extreme left part of the figure may also be less reliable, as the estimated PAH values are somewhat arbitrary as regards background levels. A few examples of fitted response curves for the species are shown in Fig. 7. The species shown are 1 echinoderm (Amphiura filiformis) and 3 polychaetes (Eclysippe vanelli, Paramphinome jeffreysii and Nereimyra punctata), representing different feeding modes. Although the examples illustrate quite typically the very scattered nature of the species data, it appears that the fitted functions describe the main distribution of the species adequately.

\section{DISCUSSION}

The assumption underlying the environmental studies in smelter-affected fjords is that PAH may have adverse effects on organisms in the receiving waters. It is common knowledge that PAHs may have severe pathological effects in fish, especially by inducing cancer and various skin. and liver lesions (see e.g. Knutzen 1995). Fairly little is known about the effects of PAHs
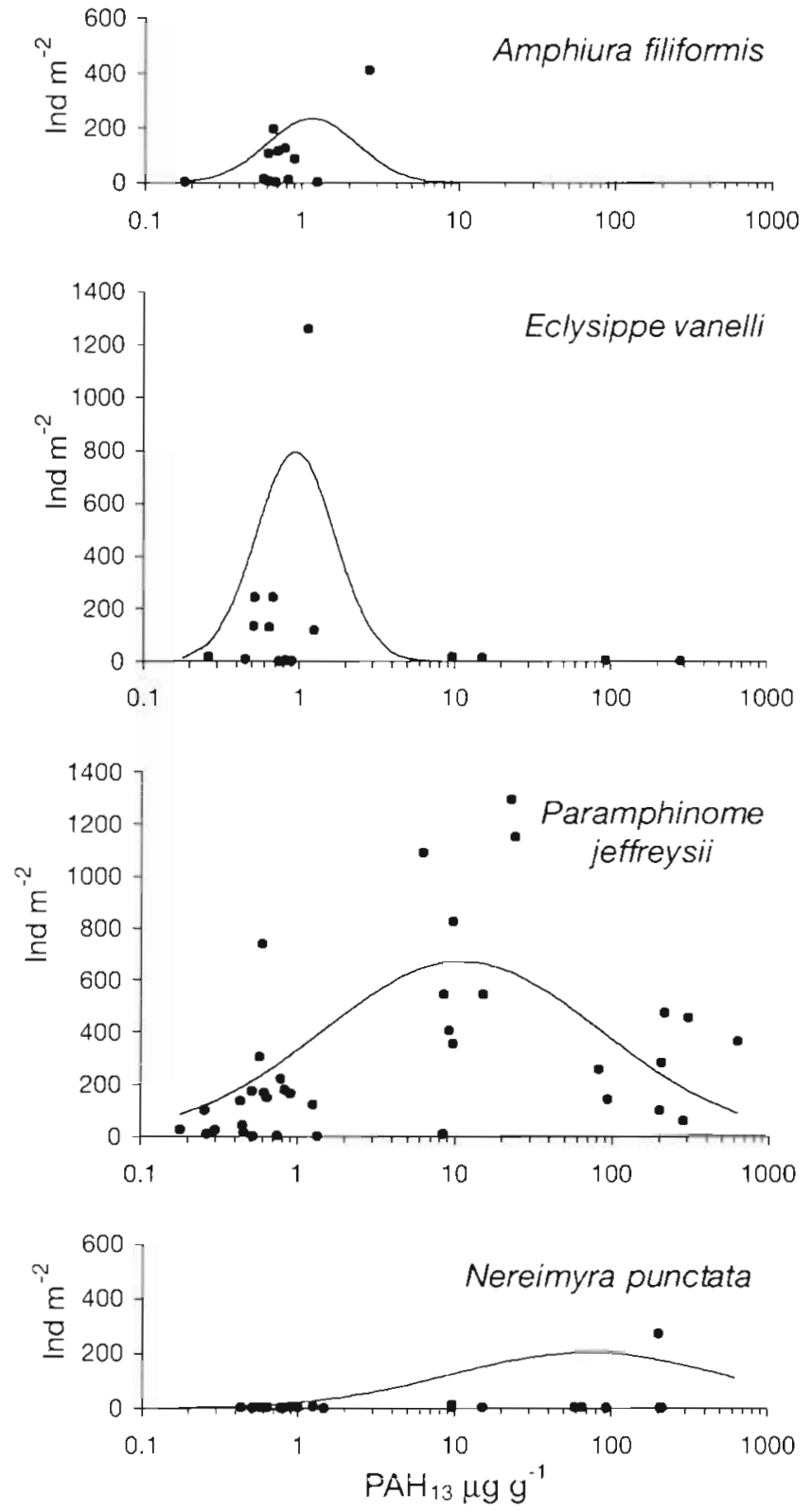

Fig. 7 Fitted response curves for species along the PAH concentration gradient showing examples of species belonging in different feeding categories. Amphiura filiformis: suspension feeding brittle star; Eclysippe vanelli: surface deposit teeding polychaete; Paramphinome jeffreysii and Nereimyra punctata: camivorous polychaetes

on other aquatic organisms. Many invertebrates, such as molluscs and crustaceans, tend to accumulate PAH without obvious detrimental effects (Law \& Biscaya 1994, Næs et al. 1995). However, various studies have reported toxic effects, even at moderate PAH concentrations (see Long 1992, Long et al. 1995). Apparently, the ability to metabolise PAH differs among species and classes of organisms, which may account for some 
of the reasons the potential hazards tend to differ among species. In polychaetes, the metabolic ability varies considerably among species and may not be predicted on the basis of standard taxonomic classifications (Driscoll \& McElroy 1996); in molluscs, the metabolic rates appear to be low. In addition, some echinoderms are known to metabolise PAHs (den Besten et al. 1993)

The actual toxicity of $\mathrm{PAH}$, however, may be fundamentally contingent on speciation of the PAHs. PAHs generated by the $\mathrm{Al}$ and $\mathrm{Mn}$-alloy industry are, to a large extent, bound to black carbon-containing particles (soot) (Næs et al. 1998). If these particulate bound PAHs should impose effects on biota, it implies desorption from the soot matrix and crossing of cell membranes. However, the association of PAHs with soot carbon is known to restrict the desorption processes (McGroddy \& Farrington 1995, McGroddy et al. 1996). Compared with petroleum-derived PAHs, the former are presumably less available to organisms. Knutzen (1995) suggested that the generally modest ecological effects observed in the Norwegian smelter-affected fjords might be explained by particle affinities. Indeed, studies of PAH profile patterns in the fjords have indicated that the PAHs are resistant to degradation and transformation reactions (Næes \& Oug 1997, 1998). Correspondingly, Paine et al. (1996) concluded that sediment PAHs present in the form of pitch or coal tar particles in smelter-affected Canadian fjords are of limited bioavailability and do not exhibit toxic effects on the benthic fauna.

Also, effects of PAHs on organisms are in general initiated through biotransformation of the compounds to toxic metabolites, mainly by activation of the cytochrome P450-enzymes. This enzyme system is well developed in fish, but to a far lesser extent in invertebrates (Bucheli \& Fent 1995).

It is generally recognised that the overall ecological effects of contaminants will be exposed through the natural communities of species, since a community represents a system of species interactions and, accordingly, integrates and reflects the responses of all affected species. The study of natural species communities is therefore a key element in many monitoring programmes addressing the spatial and temporal effects of contaminants. However, the effects may be small compared with the influences of natural abiotic factors and may also be overshadowed by large biological variation. The inherent difficulty may lie in correctly linking biotic responses and environmental influences, in particular when it comes to detecting and interpreting subtle changes (Rees \& Eleftheriou 1989, Elliott 1994). Despite the complexity of the systems, various authors (e.g. Joern \& Hoagland 1996) stress the importance of community or ecosystem stud- ies for risk assessments because single-species studies such as bioassays may fall short in predicting the responses of natural systems. As a consequence, capturing key response signals in natural systems will represent a major challenge in the field of ecotoxicology (Joern \& Hoagland 1996).

In the present examination of data from Norwegian smelter-affected fjords, significant faunal changes pertaining to trophic composition, and to some extent systematic groups, were identified along sedimentary PAH gradients. At high PAH levels detritus feeders were generally reduced while carnivores seemed to be unaffected or possibly even stimulated. The changes appeared to commence at rather low PAH levels, before the total number of species and community diversity was affected, and also before detrimental effects became obvious. Clearly, the general effects of the PAHs on the communities were limited, but the functional changes may represent a type of early response signal preceding more fundamental changes evidenced by species reductions or reduced diversity. The changes may reflect contaminant responses which influence particular species or groups of species. The most clear and diverse responses were observed among the polychaetes, which, as a group, represent a diverse range of feeding modes and living strategies. In a general context, these results emphasise that incorporating the biological features of the organisms into analyses of the species assemblages may enhance the capability of impact determination. Elliott (1994) notably encouraged such approaches in environmental quality assessments. The importance of functional relationships has recently also been demonstrated by Roth \& Wilson (1998), who found that trophic preferences afforded stronger demarcation of the patterns in intertidal sediment communities than taxonomic analyses. Interestingly, they observed a dominance of carnivores in areas with stress from anthropogenic pollution.

The presently observed faunal changes could possibly be explained in terms of exposure to PAHs. Compared with sessile particle feeders, carnivorous polychaetes may simply be less exposed as they are able to move in and out of the strongly contaminated areas. They are also less dependent on the sediments for food and shelter. The fact that the community changes tended to be most distinct in shallow waters may also point to exposure. Recent data show that the smelter effluents contain substantial amounts of low-molecular-weight PAHs in a non-particulate state, which are dispersed in the surface layers of the receiving waters (Næs et al. 1998). Further, various more toxic and soluble derived compounds may result from photo-oxidation (Ankley et al. 1997). These factors could indicate that smelter effluents influence the surface and shal- 
low waters more extensively than the deep bottom areas in receiving waters. Nevertheless, the specific responses to the PAHs will depend on the metabolic systems and tolerance to environmental stress of the individual species, which cannot easily be generalised to species groups (cf. Driscoll \& McElroy 1996). Possibly the carnivores may feed on small organisms which are not retained in the $1 \mathrm{~mm}$ mesh sieves used in the present studies.

The echinoderms represented the only systematic group which showed a negative correlation with PAH. This result ties in with recent studies in the Sunndal fjord in which biomarker responses have been detected in soft bottom sea stars and sea cucumbers (Næes et al. unpubl.). Echinoderms have also been found to be sensitive to oil pollution (Daan et al. 1992, Newton \& McKenzie 1995). For instance, in the North Sea, the population of the brittle star Amphiura filiformis decreases in response to discharges of oil-contaminated drill cuttings (Daan et al. 1992). Some echinoderms, e.g. sea stars, are known to metabolise PAHs (den Besten et al. 1993), thereby exposing themselves to increased levels of potentially deleterious metabolites. Possibly, particular attention should be paid to the echinoderms in PAH monitoring, as this group may link biomarker and ecological responses.

In the generalised diagram of changes in the community, the main rise in the proportion of carnivores occurred at PAH levels between 10 and $100 \mathrm{\mu g} \mathrm{g}^{-1}$, with the initial changes at about $5 \mathrm{\mu g} \mathrm{g}^{-1}$. Interestingly, these values are not all that distant from the effect limits for PAH established by Long et al. (1995) from a number of toxicity tests and field studies. They indicated that adverse effects first appear at about $4 \mu \mathrm{g} \mathrm{g}^{-1}$ total PAH ('effect range low'), and frequently or always occur at above $50 \mathrm{ug} \mathrm{g}^{-1}$ ('effect range median'). Long et al. (1995) assumed that the limits would be of broad applicability, because data for a variety of species, which may differ considerably in their sensitivity to contaminants, were included. It should be remembered, however, that the pattern illustrated in the present study is based on correlations between faund and PAH and does not necessarily express a direct cause and effect relationship.

It should also be considered that the species could possibly react to stressing factors other than PAH in the discharged effluents. These may include fluoride, particulate matter, and in some cases, metals (Knutzen 1995). In the present data sets, there were rather few quantitative data for these factors, so they could not be entered as separate variables in the analyses. Fluoride is potentially hazardous because it may form complexes with metals of importance for enzyme functions. Knutzen (1995), however, found it unlikely that fluoride should cause any major impairment of the environ- ment in the receiving waters, considering that effluent discharges are rapidly diluted. The deposition of particulate matter could constitute an important factor in the vicinity of the outfalls. Sedimentation of inert mineral particles, however, has elsewhere been found to favour small deposit feeding organisms (Gray 1982, Olsgard \& Hasle 1993), which is contrary to the pattern found in the present study. Metal contaminants are of concern in fjords affected from Mn-alloy smelters (Feda, Sauda) but not from Al smelters ( $\AA$ rdal, Sunndal), because of the different ore materials. In the Sunndal fjord, metal concentrations are low (Knutzen 1995). Essentially, the separate CCA for the Sunndal and Surnadal fjords revealed the same pattern among the carnivores as the main analysis, ruling out metals in this case. In conclusion, PAH is therefore, as far as is known, the only major consistent stressing factor which is present in the smelter-affected fjords and to which species patterns may be related. It should also be noted that in the CCAs, stressing factors other than PAH would contribute to the non-specific variables of distance from effluent outfall and sediment categories, which in the analyses were found to be less clearly related to species patterns than PAH.

The fractions of the species variance which could be accounted for by the environmental variables in the 2 CCAs were roughly 20 and $50 \%$, respectively. These figures are comparable to other benthic studies explaining 25 to $40 \%$ of the variance using variables related to topography, sediments, and, in some cases, contaminants (Quintino et al. 1995, Mackie et al. 1997. Oug 1998). The unexplained variance possibly represents important ecological factors which have not been characterised, as well as generally inexplicable 'noise' emanating from patchiness and random fluctuations in the biological systems. The CCA technique, however, provides a framework for estimating and testing particular species-environment relationships, even when these are masked by other large sources of variation (ter Braak \& Verdonschot 1995). In the present case, the species patterns extracted on the PAH gradient represented no more than 5 to $10 \%$ of the total variance. These patterns were not observed in the traditional treatment of the species data. Essentially, this result corroborates Elliott (1994), who pointed out that the routine analyses most commonly applied to benthic community data do not fully extract the biological information contained in the data. In order to correctly interprete such patterns and evaluate the ecological consequences, however, it is important to describe and quantify the influences of natural environmental factors as completely as possible. This points to a need to characterise a broader set of environmental variables and ecological relationships in monitoring of the effects of contaminants. 
Acknowledgements. The data were obtained under a national monitoring programme administered by the Norwegian Pollution Control Authority (SFT) and implemented by the Norwegian Institute for Water Research (NIVA). We thank the following financial sources: Elkem ANS Lista, Elkem ANS Mosjøen, Elkem Mangan Sauda, Elkem Mangan PEA, Hydro Aluminium Høyanger, Hydro Aluminium Karmøy, Hydro Aluminium Sunndal, Hydro Aluminium Årdal, Tinfos Jernverk a.s. Oye Smelteverk, the Norwegian Pollution Control Authority, the Research Council of Norway (Programme FORFOR - Research Programme for Sustainable Development) and the Norwegian Institute for Water Research. We also thank an advisory committee made up of members from the above institutions for its participation and comments on the manuscript: Eirik Nordheim, Magne Leinum, Ame Kjellsen, Anders Bruusgaard, Per Erik Iversen and Jens Skei. We are indebted to Knut Arrestad and Jorunn Larsen (Univ. of Bergen) for help and comments on the numerical analyses, and to Linda Sivesind and Peter Stanton for linguistic corrections.

\section{LITERATURE CITED}

Ankley GGT, Erickson JRJ, Sheedy BR, Kosian PC, Mattson VR, Cox JS (1997) Evaluation of models for prediction of the phototoxic potency of polycyclic aromatic hydrocarbons. Aquat Toxicol 37:37-50

Bucheli TD, Fent K (1995) Induction of the cytochrome P450 as a biomarker for environmental contamination in aquatic ecosystems. Crit Rev Environ Sci Techol 25: $201-268$

Daan $R$, van het Groenewoud $H$, de Jong $S A$, Mulder $M$ (1992) Physico-chemical and biological features of a drilling site in the North Sea, 1 year after discharges of oilcontaminated drill cuttings. Mar Ecol Prog Ser 91:37-45

den Besten PJ, Lemaire P, Livingstone DR, Woodin B, Stegeman JJ, Herwig HJ, Seinen W (1993) Time-course and dose-response of the apparent induction of the cytochrome P450 monooxygenase system of pyloric caeca microsomes of the female sea star Asterias rubens L. by benzo(a)pyrene and polychlorinated biphenyls. Aquat Toxicol 26:23-40

Driscoll SK, McElroy AE (1996) Bioaccumulation and metabolism of benzo(a)pyrene in three species of polychaete worms. Environ Toxicol Chem 15:1401-1410

Elliott $M$ (1994) The analysis of macrobenthic community data. Mar Pollut Bull 28:62-64

Fauchald K, Jumars PA (1979) The diet of worms: a study of polychaete feeding guilds. Oceanogr Mar Biol Annu Rev $17: 193-284$

Gaston GR (1987) Benthic Polychaeta of the Middle Atlantic Bight: feeding and distribution. Mar Ecol Prog Ser 36: $251-262$

Gray JS (1982) Effects of pollutants on marine ecosystems. Neth J Sea Res 16:424-443

Joern A, Hoagland KD (1996) In defence of whole-community bioassays for risk assessment. Environ Toxicol Chem 15: $407-409$

Jongman RHG, ter Braak CJF, van Tongeren OFR (1987) Data analysis in community and landscape ecology. Pudoc, Wageningen

Josefson AB (1986) Temporal heterogeneity in deep-water soft-sediment benthos. An attempt to reveal temporal structure. Estuar Coast Shelf Sci 23:147-169

Knutzen $J$ (1995) Effects on marine organisms from polycyclic aromatic hydrocarbons (PAH) and other constituents of waste water from aluminium smelters with examples from Norway. Sci Total Environ 163:107-122

Law RJ, Biscaya JL (1994) Polycyclic aromatic hydrocarbons (PAH) - problems and progress in sampling, analysis and interpretation. Mar Pollut Bull 29:235-241

Long ER (1992) Ranges in chemical concentrations in sediments associated with adverse biological effects. Mar Pollut Bull 24:38-45

Long ER, MacDonald DD, Smith SL, Calder FD (1995) Incidence of adverse biological effects within ranges of chemical concentrations in marine and estuarine sediments. Environ Manag 19:81-97

Mackie ASY, Parmiter C, Tong LKY (1997) Distribution and diversity of Polychaeta in the southern lrish Sea. Bull Mar Sci $60: 467-481$

McGroddy SE, Farrington JW (1995) Sediment porewater partitioning of polycyclic aromatic hydrocarbons in three cores from Boston Harbor, Massachusetts. Environ Sci Technol 29:1542-1550

McGroddy SE, Farrington JW, Gschwend PM (1996) Comparison of the in situ and desorption sediment-water partitioning of polycyclic aromatic hydrocarbons and polychlorinated biphenyls. Environ Sci Technol 30:172-177

Molvær J, Knutzen J, Magnusson J, Rygg B, Skei J, Sørensen $\mathrm{J}$ (1997) Classification of environmental quality in fjords and coastal waters. A guide. Norwegian Pollution Control Authority, Oslo

Naes K, Axelman J, Näf C, Broman D (1998) Role of soot carbon and other carbon matrices in the distribution of PAHs among particles, DOC, and the dissolved phase in the effluent and recipient waters of an aluminium reduction plant. Environ Sci Technol 32:1786-1792

Næs K, Knutzen J, Berglind L (1995) Occurrence of PAH in marine organisms and sediments from smelter discharge in Norway. Sci Total Environ 163:93-106

Næs K. Oug E (1997) Multivariate approach to distribution patterns and fate of polycyclic aromatic hydrocarbons in sediments from smelter-affected Norwegian fjords and coastal waters. Environ Sci Technol 31:1253-1258

Næs K, Oug E (1998) The distribution and environmental relationships of polycyclic aromatic hydrocarbons (PAHs) in sediments from Norwegian smelter-affected fjords. Chemosphere 36:561-576

Newton LC, McKenzie JD (1995) Echinoderms and oil pollution: a potential stress assay using bacterial symbionts. Mar Pollut Bull 31:453-456

Olsgard F, Gray JS (1995) A comprehensive analysis of the effects of offshore oil and gas exploration and production on the benthic communities of the Norwegian continental shelf. Mar Ecol Prog Ser 122:277-306

Olsgard F, Hasle JR (1993) Impact of waste from titanium mining on benthic fauna. J Exp Mar Biol Ecol 172 : $185-213$

Oug E (1998) Relating species patterns and environmental variables by canonical ordination: an analysis of softbottom macrofauna in the region of Tromse, northern Norway. Mar Environ Res 45:29-45

Paine MD, Chapman PM, Allard PJ, Murdoch MH, Minifie D (1996) Limited bioavailability of sediment PAH near an aluminum smelter contamination does not equal effects Environ Toxicol Chem 15:2003-2018

Quintino V, Picado AM, Rodrigues AM, Mendonca E, Costa MH, Bordalo Costa M, Lindgaard-Jorgensen P, Pearson $\mathrm{TH}$ (1995) Sediment chemistry-infaunal community structure in a southern European estuary related to solidphase Microtox toxicity testing. Neth J Aquat Ecol 29: $427-436$ 
Rees HL, Eleftheriou A (1989) North Sea benthos: a review of field investigations into the biological effects of man's activities. J Cons Int Explor Mer 45:284-305

Roth S, Wilson JG (1998) Functional analysis by trophic guilds of macrobenthic community structure in Dublin Bay, Ireland. J Exp Mar Biol Ecol 222:195-217

Smilauer P (1992) CanoDraw. User guide ver 3.0. Environmental Change Research Centre University College, London

ter Braak CJF (1986) Canonical correspondence analysis: a

Editorial responsibility: Otto Kinne (Editor)

Oldendorf/Luhe, Germany new eigenvector technique for multivariate direct gradient analysis. Ecology 67:1167-1179

ter Braak CJF (1988) Canoco - a Fortran program for canonical community ordination. Ministerie van Landbouw en Visserij, Groep Landbouwwiskunde, Wageningen

ter Braak CJF (1990) Update notes. CANOCO ver 3.1 Agricultural Mathematics Group, Wageningen

ter Braak CJF, Verdonschot PFM (1995) Canonical correspondence analysis and related multivariate methods in aquatic ecology. Aquat Sci 57:255-289

Submitted: November 11, 1997; Accepted: July 31, 1998 Proofs received from author(s): October 12, 1998 